\title{
Growth and mineral content of young chestnut trees under controlled conditions of nutrition
}

\author{
A Laroche, V Freyssac, A Rahmani, JP Verger*, H Morvan \\ Laboratoire de biologie cellulaire végétale et valorisation des espèces ligneuses, \\ faculté des sciences, 123, rue A-Thomas, 87060 Limoges cedex, France
}

(Received 23 August 1996; accepted 3 March 1997)

\begin{abstract}
Summary - The growth of young forest trees under conditions of controlled nutrition, limiting export and import of nutrients, is an efficient tool to obtain a rapid understanding of the direct effects of fertilization. This approach reveals the ability of chestnut trees to (i) grow in a poor soil with no additional supply of minerals for at least 2 years and (ii) draw elements from the mineral reserve of the soil. The growth of trees is enhanced by supplying nutrients, especially NPK. These nutrients directly modify the element availability in the soil and increase its $\mathrm{pH}$. They also induce variations in cation content within different organs, eg, significant increases in calcium and magnesium but not in potassium content. Moreover, manganese seems to be important for the cationic balance in all organs as it is accumulated when trees are unfertilized but not when quick-lime is supplied.
\end{abstract}

\section{calcium / Castanea sativa / fertilization / growth / mineral nutrition}

Résumé - Croissance et contenu minéral de jeunes châtaigniers cultivés en conditions nutritives contrôlées. La culture contrôlée de jeunes arbres forestiers, en limitant les entrées et sorties d'éléments minéraux, permet d'évaluer rapidement les effets directs de la fertilisation. Ainsi, le châtaignier est capable de pousser pendant au moins deux ans sur un substrat pauvre et sans amendement, montrant ainsi son aptitude à puiser des éléments dans la réserve minérale du sol. Toutefois, une fertilisation, notamment par NPK, améliore sa croissance. Ces apports modifient la disponibilité des éléments dans le sol, y augmentent le $\mathrm{pH}$ et provoquent des variations des contenus cationiques dans les arbres : augmentation des teneurs en calcium et en magnésium mais pas en potassium. Cependant, le manganèse semble jouer un rôle important dans la balance cationique, puisqu'il s'accumule dans les arbres non fertilisés et qu'un apport de chaux vive provoque l'effet inverse.

calcium / Castanea sativa / croissance / fertilisation / nutrition minérale

\footnotetext{
* Correspondence and reprints

Tel: (33) 0555457381 ; fax: (33) 05554573 86; e-mail: lbcvel@unilim.fr
} 


\section{INTRODUCTION}

Growth of trees is generally related to mineral nutrition. Some deficiencies greatly affect growth, when cations are lacking (Shear and Faust, 1980; Spiers and Braswell, 1994) and particularly calcium deficiency (Davis, 1949; Ramalho et al, 1995). However, the chestnut tree is known for its ability to grow on poor ground (Bourgeois, 1992). In spite of interesting chemical and physical wood qualities, a wood failure known as ringshake frequently occurs with disastrous marketing consequences. Chanson et al (1989) have hypothesized that this cohesion breakdown is located in the middle lamella, a cell wall area rich in pectins. These acid polysaccharides are known to be stabilized by calcium (Demarty et al, 1984; Jarvis, 1984) and involved in modification of cell adhesion (Liners et al, 1994). These data suggest the potential role of calcium in ringshake. Thus, this wood failure could be related to calcium nutrition and its availability in soil.

Soils in the Limousin (France) are acidic and relatively poor in available nutrients (Verger et al, 1985, 1994). The aim of the present work was to determine whether fertilizer treatments can modify the growth of young chestnut trees grown in these soils and affect the cation content of different organs (roots, bark, de-barked stems, leaves), especially divalent cations. This study was carried out in a greenhouse in order to limit cation imports and exports and to control environmental factors.

\section{MATERIAL AND METHODS}

\section{Material}

One-year-old chestnut trees (Castanea sativa Miller) were planted in March 1994 in 8-L PVC pots. The culture substratum was composed of a $\mathrm{C}$ horizon of Limousin (middle west of France) chestnut forest soil (mesotropic brown soil) mixed with river sand $(2: 1$ weight ratio), which represented a poor exchangeable mineral element substratum. This substratum was acidic $\left(\mathrm{pH} \mathrm{H}_{2} \mathrm{O}=5.1 ; \mathrm{pH} \mathrm{KCl}=4.3\right)$ and was characterized by a very low cation exchange capacity of 1.32 cmolc. $\mathrm{kg}^{-1}$ with exchangeable basic cations: $\mathrm{Ca}^{2+}: 0.30$ cmolc. $\mathrm{kg}^{-1} ; \mathrm{Mg}^{2+}: 0.12$ cmolc. $\mathrm{kg}^{-1}$; $\mathrm{K}^{+}: 0.18$ cmolc. $\mathrm{kg}^{-}$and a total acid cations: $\mathrm{H}^{+}$: 0.15 cmolc.kg ${ }^{-1} ; \mathrm{Al}^{3+}: 0.40$ ) cmolc.kg ${ }^{-1}$ (Freyssac et al, 1994).

Ten young trees were kept in order to quantify the element contents at the time of planting. The others were distributed between five different fertilizer treatment groups ( 20 trees each).

\section{Fertilizer supplies}

The young plants were grown under five different sets of conditions, A, B, C, D and O.

A consisted of a single supply of quick-lime $\left(2 \mathrm{cmolc}\right.$ of $\mathrm{Ca}^{2+} / \mathrm{kg}$ of soil, corresponding to $1000 \mathrm{~kg} \cdot \mathrm{ha}^{-1}(94.0 \% \mathrm{CaO})$ for forest fertilization);

$\mathrm{B}$ consisted of a single supply of $\mathrm{Ca}+\mathrm{Mg}(2$ cmolc of $\mathrm{Ca}^{2+}$ and 0.5 cmolc of $\mathrm{Mg}^{2+}$ per kg of soil, corresponding to $2000 \mathrm{~kg} \cdot \mathrm{ha}^{-1}(42.0 \% \mathrm{CaO}$ $+10.0 \% \mathrm{MgO})$ );

C consisted of B conditions + macroelements (ammonium nitrate, potassium oxide and phosphate at $500 \mathrm{~kg} \cdot \mathrm{ha}^{-1}$, for $\mathrm{N}\left(16.8 \% \mathrm{~N}-\mathrm{NO}_{3}\right.$, $\left.16.8 \% \mathrm{~N}-\mathrm{NH}_{4}\right)$ and also for PK $\left(18.5 \% \mathrm{P}_{2} \mathrm{O}_{5}\right.$, $\left.24.0 \% \mathrm{~K}_{2} \mathrm{O}\right)$ );

D consisted of $\mathrm{C}$ conditions + trace elements (Calmagol H, Holimco, $50 \mathrm{~kg} \cdot \mathrm{ha}^{-1}$ with a composition of: $\mathrm{Ca}: 32.5 \%, \mathrm{Mg}: 3.3 \%, \mathrm{Fe}: 0.7 \%$, $\mathrm{Mn}: 0.007 \%, \mathrm{Cu}, \mathrm{Co}$ and Ni traces);

$\mathrm{O}$ was a control with no additional elements.

The letters A, B, C, D and $\mathrm{O}$ will be taken to mean the trees and/or conditions under which they were grown.

The fertilizers were mixed into the substratum, pot by pot, before planting. Experiments were performed in semi-controlled conditions in the greenhouse with temperature measurement. The temperature varied from a minimum of $2{ }^{\circ} \mathrm{C}$ during the winter to a maximum of $45^{\circ} \mathrm{C}$ in the summer. Being protected against rain fall, the trees were watered with deionized water exclusively between one and eight times per month depending on temperature. Moreover, leaves from each batch were collected when they fell, 
then reduced to a powder for further analysis. An aliquot was used for mineral composition (data not shown) and the rest was added, in late January 1995, to the surface of the corresponding substratum of the trees that were not destructively harvested.

\section{Methods}

Growth parameters, such as height, base diameter (at soil surface), number of branches and sum of annual shoot length, were measured for each tree in March 1994 (planting), September 1994 and June 1995.

The fourth leaf from each apex was gathered 15 days before harvesting in September 1994 and June 1995, and also the foliage of trees was harvested in order to estimate the leaf area by cutting up and weighing paper copies.

Trees were grouped into three categories for each treatment: small, medium and large, according to the sum of annual shoot length. Three plants, the medium-sized trees of each category, were harvested to provide material for mineral content at each harvest time except at initial planting when six trees were randomly sampled. Roots (washed with deionized water), bark, leaves and de-barked stems were manually separated and oven dried at $80^{\circ} \mathrm{C}$ for $2 \mathrm{~h}$ then at $60^{\circ} \mathrm{C}$ for $48 \mathrm{~h}$ (to a constant mass). Plant materials were then weighed and powdered using a ball-tearing shaker. Except for current year de-barked stems of which there was insufficient quantity, $0.2 \mathrm{~g}$ of each sample was weighed out and digested for $10 \mathrm{~min}$ at $600{ }^{\circ} \mathrm{C}$ in $14 \mathrm{~mL}$ of a $2: 6: 6(\mathrm{v} / \mathrm{v} / \mathrm{v})$ mixture of $\mathrm{H}_{2} \mathrm{SO}_{4}, \mathrm{HNO}_{3}$ and $\mathrm{H}_{2} \mathrm{O}_{2}$ according to Hoenig and Vanderstappen (1978). Concentrations of $\mathrm{Ca}, \mathrm{Mg}$ and $\mathrm{Mn}$ were determined by atomic absorption and $\mathrm{K}$ contents by atomic emission spectrophotometry (Atomspek H1170Hilger \& Watts).

The substrata of the three harvested plants for each treatment were mixed together at harvest time (September 1994, January 1995 and June 1995). As powdered leaves were applied in January 1995, the upper $5 \mathrm{~cm}$, where there were no roots, were not taken into account. The $\mathrm{pH}$ of the air-dried and sieved $(2 \mathrm{~mm})$ samples of substratum was measured in deionized water $(\mathrm{w} / \mathrm{w}$, 2:5) after standing overnight. The $\mathrm{pH}$ was also determined for samples collected in March 1994 before planting.

\section{Statistical analysis}

Growth parameter analyses were expressed as the mean of 20 individual values at the beginning of the study, to 10 individual values at the end, and the Mann and Whitney U test (1947) was applied with a threshold of $5 \%$.

Mineral analyses were performed individually, on three different trees for each treatment at the sampling date. Results were expressed as the mean of the three values and the Mann and Whitney $U$ test (1947) was again applied, with a threshold of $5 \%$.

\section{RESULTS}

\section{Growth parameters}

At the time of planting (March 1994), the heights of the 1 -year-old chestnut trees ranged from 22 to $52 \mathrm{~cm}$. The mean heights (table I) and base diameters (table II) of trees

Table I. Average height of chestnut trees $(\mathrm{cm})$ in relation to fertilizer supplies. Each value represents a mean \pm SE from 10 to 20 trees. Values in rows followed by the same letter are not significantly different (threshold of 5\%) according to Mann and Whitney U test (1947). Fertilizer treatments correspond to (O) control unfertilized, (A) a quick-lime, (B) a calcomagnesian, (C) a macroelement and (D) macro + microelement supplies.

\begin{tabular}{lccccc}
\hline Date & $O$ & $A$ & $B$ & $C$ & $D$ \\
\hline March 94 & $35.5 \pm 1.3 \mathrm{a}$ & $32.4 \pm 1.6 \mathrm{a}$ & $35.2 \pm 1.8 \mathrm{a}$ & $35.3 \pm 1.3 \mathrm{a}$ & $34.4 \pm 1.6 \mathrm{a}$ \\
Sept 94 & $45.5 \pm 2.4 \mathrm{a}$ & $42.5 \pm 2.1 \mathrm{a}$ & $45.5 \pm 2.6 \mathrm{a}$ & $47.3 \pm 2.3 \mathrm{a}$ & $48.4 \pm 2.3 \mathrm{a}$ \\
June 95 & $51.5 \pm 3.1 \mathrm{a}$ & $46.8 \pm 2.8 \mathrm{ab}$ & $46.9 \pm 3.3 \mathrm{ab}$ & $54.5 \pm 2.2 \mathrm{bc}$ & $62.6 \pm 3.9 \mathrm{c}$ \\
\hline
\end{tabular}


Table II. Average base diameter of chestnut trees $(\mathrm{mm})$ in relation to fertilizer supplies. Each value represents a mean \pm SE from 10 to 20 trees. Values in rows followed by the same letters are not significantly different (threshold of 5\%) according to Mann and Whitney U test (1947). Abbreviations for treatments are the same as those in table $\mathrm{I}$.

\begin{tabular}{lccrrr}
\hline Date & $O$ & $A$ & $B$ & $C$ & \multicolumn{1}{c}{$D$} \\
\hline March 94 & $8.2 \pm 0.2 \mathrm{a}$ & $6.9 \pm 0.3 \mathrm{~b}$ & $8.6 \pm 0.4 \mathrm{a}$ & $8.5 \pm 0.3 \mathrm{a}$ & $8.0 \pm 0.3 \mathrm{a}$ \\
Sept 94 & $9.6 \pm 0.3 \mathrm{ab}$ & $9.0 \pm 0.3 \mathrm{a}$ & $10.1 \pm 0.4 \mathrm{bc}$ & $10.8 \pm 0.2 \mathrm{c}$ & $10.1 \pm 0.2 \mathrm{~b}$ \\
June 95 & $10.1 \pm 0.4 \mathrm{a}$ & $9.6 \pm 0.4 \mathrm{ab}$ & $11.3 \pm 0.6 \mathrm{bc}$ & $11.7 \pm 0.4 \mathrm{c}$ & $11.4 \pm 0.3 \mathrm{c}$
\end{tabular}

Table III. Sum of annual shoot length of chestnut trees $(\mathrm{cm})$ in relation to fertilizer supplies and number of ramifications, in parentheses. Each value represents a mean $\pm S E$ from 10 to 20 trees. Values in rows followed by the same letters are not significantly different (threshold of $5 \%$ ) according to Mann and Whitney U test (1947). Abbreviations for treatments are the same as those in table I.

\begin{tabular}{|c|c|c|c|c|c|}
\hline Date & $O$ & $A$ & $B$ & $C$ & $D$ \\
\hline Sept 94 & $\begin{array}{c}36.0 \pm 3.9 \mathrm{ab} \\
(4.5 \pm 0.4 \mathrm{a})\end{array}$ & $\begin{array}{l}32.2 \pm 3.0 \mathrm{a} \\
(4.2 \pm 0.3 \mathrm{a})\end{array}$ & $\begin{array}{l}39.5 \pm 5.0 \mathrm{abc} \\
(5.5 \pm 0.6 \mathrm{a})\end{array}$ & $\begin{array}{l}51.0 \pm 3.4 c \\
(5.2 \pm 0.6 a)\end{array}$ & $\begin{array}{c}48.2 \pm 4.5 b c \\
(4.3 \pm 0.4 a)\end{array}$ \\
\hline June 95 & $\begin{array}{l}10.1 \pm 1.6 a b \\
(6.6 \pm 0.7 a)\end{array}$ & $\begin{array}{c}9.8 \pm 1.9 \mathrm{a} \\
(7.0 \pm(0.8 \mathrm{a})\end{array}$ & $\begin{array}{l}15.0 \pm 2.1 \mathrm{~b} \\
(8.9 \pm 1.3 \mathrm{ab})\end{array}$ & $\begin{array}{c}44.2 \pm 3.9 \mathrm{c} \\
(13.4 \pm 1.4 \mathrm{c})\end{array}$ & $\begin{array}{c}44.5 \pm 2.9 \mathrm{c} \\
(11.8 \pm 1.5 \mathrm{bc})\end{array}$ \\
\hline
\end{tabular}

were similar for all treatments except $\mathrm{A}$, where the trees were $10 \%$ smaller than those in the other treatments, by chance.

Six months later (September 1994), the heights of the trees varied individually from 28 to $66 \mathrm{~cm}$ but the treatment mean values were not significantly different (table I). The same pattern was observed in the diameter measurements (table II). In September 1994, significant increases in the sums of the shoot length were observed in $\mathrm{C}$ and $\mathrm{D}$ compared to $\mathrm{O}$ and $\mathrm{A}$ (table III). The $\mathrm{B}$ trees produced an intermediate effect. However, no significant effect was seen in terms of the number of ramifications.

During the second growing season (June 1995), the C and D trees were signilicantly greater in terms of all growth parameters measured, especially for the sums of shoot length, which were four times greater than in O (tables I, II and III). As far as all measurements were concerned. no significant effects were observed for A. A slight effect was observed for treatment $\mathrm{B}$, in comparison with $\mathrm{O}$, but only the diameters were significantly higher (table II).

From 1994, the area of the fourth leaf of the $D$ trees was significantly higher than that of $\mathrm{O}$ trees (table IV). This difference

Table IV. Average leaf area of the fourth leaf of chestnut trees $\left(\mathrm{cm}^{2}\right)$ in relation to fertilizer supplies. Each value represents a mean $\pm S E$ from 10 to 20 trees. Values in columns followed by the same letters are not significantly different (threshold of 5\%) according to Mann and Whitney $U$ test (1947). Abbreviations for treatments are the same as those in table I.

\begin{tabular}{lll}
\hline Treatments & September 94 & \multicolumn{1}{c}{ Jume 9.5} \\
\hline O & $37.2 \pm 14.6 \mathrm{a}$ & $33.1 \pm 6.9 \mathrm{ab}$ \\
A & $39.5 \pm 16.3 \mathrm{ab}$ & $30.4 \pm 15.1 \mathrm{a}$ \\
B & $38.9 \pm 19.1 \mathrm{ab}$ & $35.4 \pm 12.2 \mathrm{ab}$ \\
C & $45.2 \pm 22.5 \mathrm{ab}$ & $50.0 \pm 14.3 \mathrm{c}$ \\
D & $50.6 \pm 18.2 \mathrm{~b}$ & $55.0 \pm 25.1 \mathrm{c}$ \\
\hline
\end{tabular}


Table V. Average foliage surface of chestnut trees $\left(\mathrm{cm}^{2}\right)$ in relation to fertilizer supplies. Each value represents a mean \pm SE from three trees. Values in columns followed by the same letters are not significantly different (threshold of $5 \%$ ) according to Mann and Whitney $U$ test (1947). Abbreviations for treatments are the same as those in table I.

\begin{tabular}{lcc}
\hline Treatments & September 94 & June 95 \\
\hline O & $698 \pm 282 \mathrm{abc}$ & $420 \pm 213 \mathrm{a}$ \\
$\mathrm{A}$ & $653 \pm 253 \mathrm{ab}$ & $445 \pm 337 \mathrm{ab}$ \\
$\mathrm{B}$ & $615 \pm 114 \mathrm{a}$ & $775 \pm 175 \mathrm{~b}$ \\
$\mathrm{C}$ & $1068 \pm 356 \mathrm{abc}$ & $1605 \pm 180 \mathrm{c}$ \\
$\mathrm{D}$ & $938 \pm 88 \mathrm{c}$ & $1485 \pm 230 \mathrm{c}$ \\
\hline
\end{tabular}

was even greater in June 1995, depending on the fertilizer supplies. Thus, C and D induced a significant increase in the area of the 4th leaf compared to the other treatments. Moreover, the total foliage area showed the same trend (table V). In 1995, this value was four times greater in $C$ and $D$, and intermediate in $\mathrm{B}$ trees compared to $\mathrm{O}$ and $A$ trees.

\section{pH substratum evolution}

Before both fertilization treatments and planting, the $\mathrm{pH}$ of the substratum was 5.1 but increased to $\mathrm{pH} 6.4$ where quick-lime (calcium supply) was added. Furthermore,

Table VI. Substratum $\mathrm{pH}$ values in relation to fertilizer supplies. Each value represents a $\mathrm{pH}$ value of a mixture of three total substrata. Abbreviations for treatments are the same as those in table I.

\begin{tabular}{lccccc}
\hline Date & $O$ & $A$ & $B$ & $C$ & $D$ \\
\hline March 94 & 5.1 & 6.4 & 6.9 & 6.8 & 6.8 \\
Sept 94 & 5.1 & 6.0 & 7.1 & 7.5 & 7.4 \\
Jan 95 & 5.1 & 6.2 & 7.3 & 7.2 & 7.3 \\
June 95 & 5.2 & 6.1 & 7.5 & 7.7 & 7.1 \\
\hline
\end{tabular}

the $\mathrm{pH}$ was greater $(6.8-6.9)$ where the substrata were supplemented with the other fertilizers (table VI). The substratum $\mathrm{pH}$ remained acidic and stable under $\mathrm{O}$ and slight acidification was observed under A. In contrast, $\mathrm{pH}$ values increased slightly but irregularly under other conditions, during the experimental period.

\section{Mineral contents}

At each sampling date, the root $\mathrm{Ca}$ levels (fig la) were at least twice as high where fertilizer was supplied (A, B, C and D) than without $(\mathrm{O})$. Under $\mathrm{O}$, a very low $\mathrm{Ca}$ concentration was observed in September 1994, which increased significantly as early as January 1995 and was found to be identical in September 1995 (four times less in 1994 than in January and September 1995). As early as September 1994, the same trend, ie, an increase in Ca between September 1994 and January 1995 and a slight variation until September 1995, was observed but less markedly for the same set of conditions. The root Mg levels in September 1994 (fig lb) were greater by up to $75 \%$ for trees supplied with $\mathrm{Mg}$ (B, C and D), compared to those that did not receive $\mathrm{Mg}(\mathrm{O}, \mathrm{A})$. In September 1995, Mg levels were $25 \%$ lower than in 1994 in all cases. The $\mathrm{K}$ levels (fig lc) showed a slight treatment effect where K was supplied (C and D) in September 1994. And a decreasing trend of K concentrations occurred under $\mathrm{O}$ and $\mathrm{A}$ between January and September 1995 and under C and D between September 1994 and September 1995. The Mn levels (fig Id) were twice as high without fertilizer $(\mathrm{O})$ than under other conditions and increased in the second year, especially in $\mathrm{O}$ but not for D.

The $\mathrm{Ca}$ levels in de-barked stem (fig $2 \mathrm{a}$ ) showed a significant increase (double) from September 1994 to September 1995 for A, $\mathrm{C}, \mathrm{D}$ and $\mathrm{O}$ but not for $\mathrm{B}$. The increase in $\mathrm{Ca}$ concentration when calcium was applied 

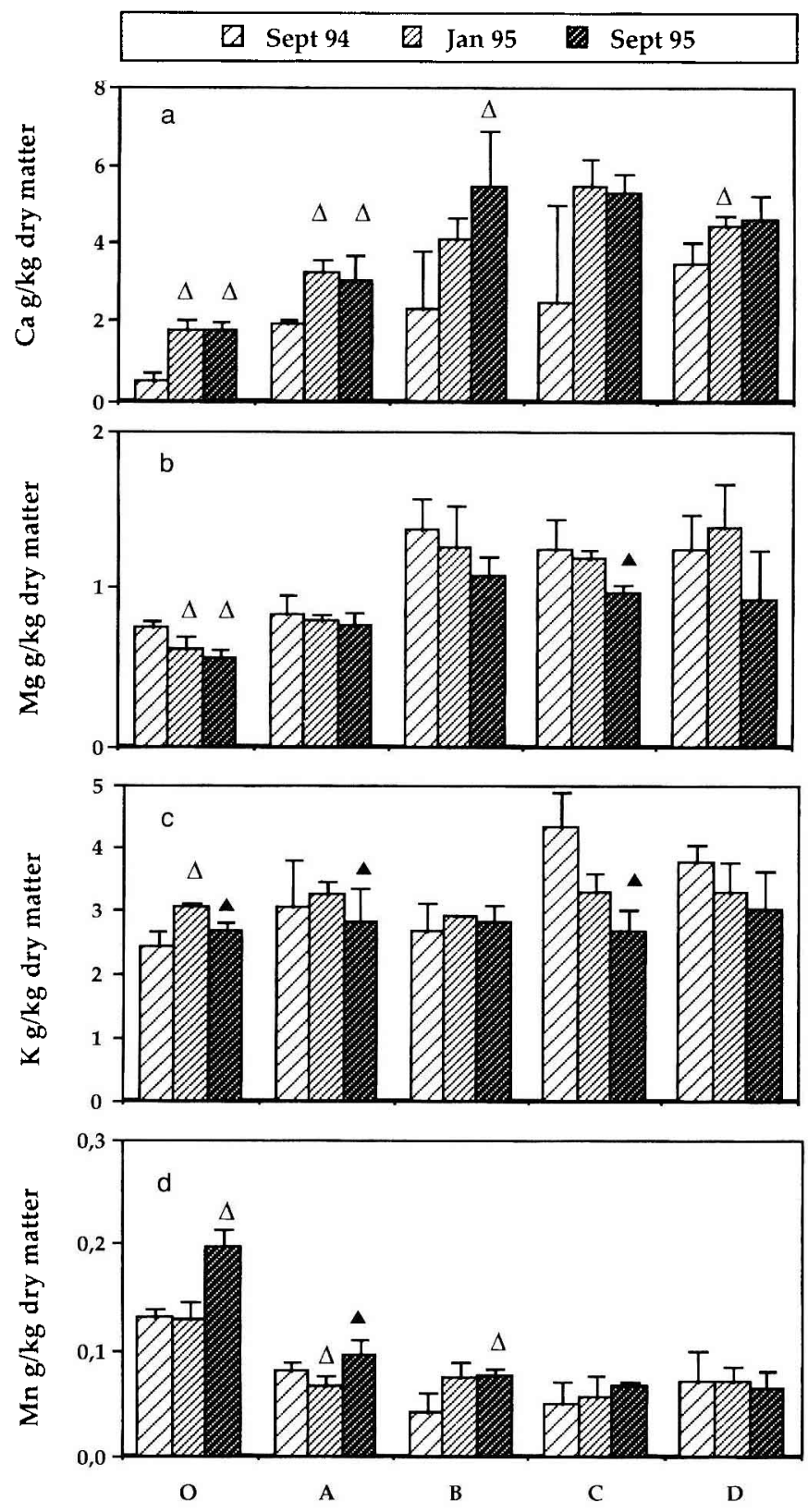

Fig 1. Effects of fertilization on calcium (a), magnesium (b), potassium (c) and manganese (d) concentrations ( $\mathrm{g} \mathrm{kg}^{-1}$ dry matter) in chestnut roots. $(\wedge)$ and $(\Delta)$ cation concentrations varying significantly in comparison with September 1994 and January 1995, respectively, by Mann-Whitney U test (threshold $5 \%$ ). Fertilizer treatments correspond to (O) control unfertilized, (A) a quick-lime, (B) a calcomagnesian, (C) a macroelement and (D) macro + microelement supplies. 

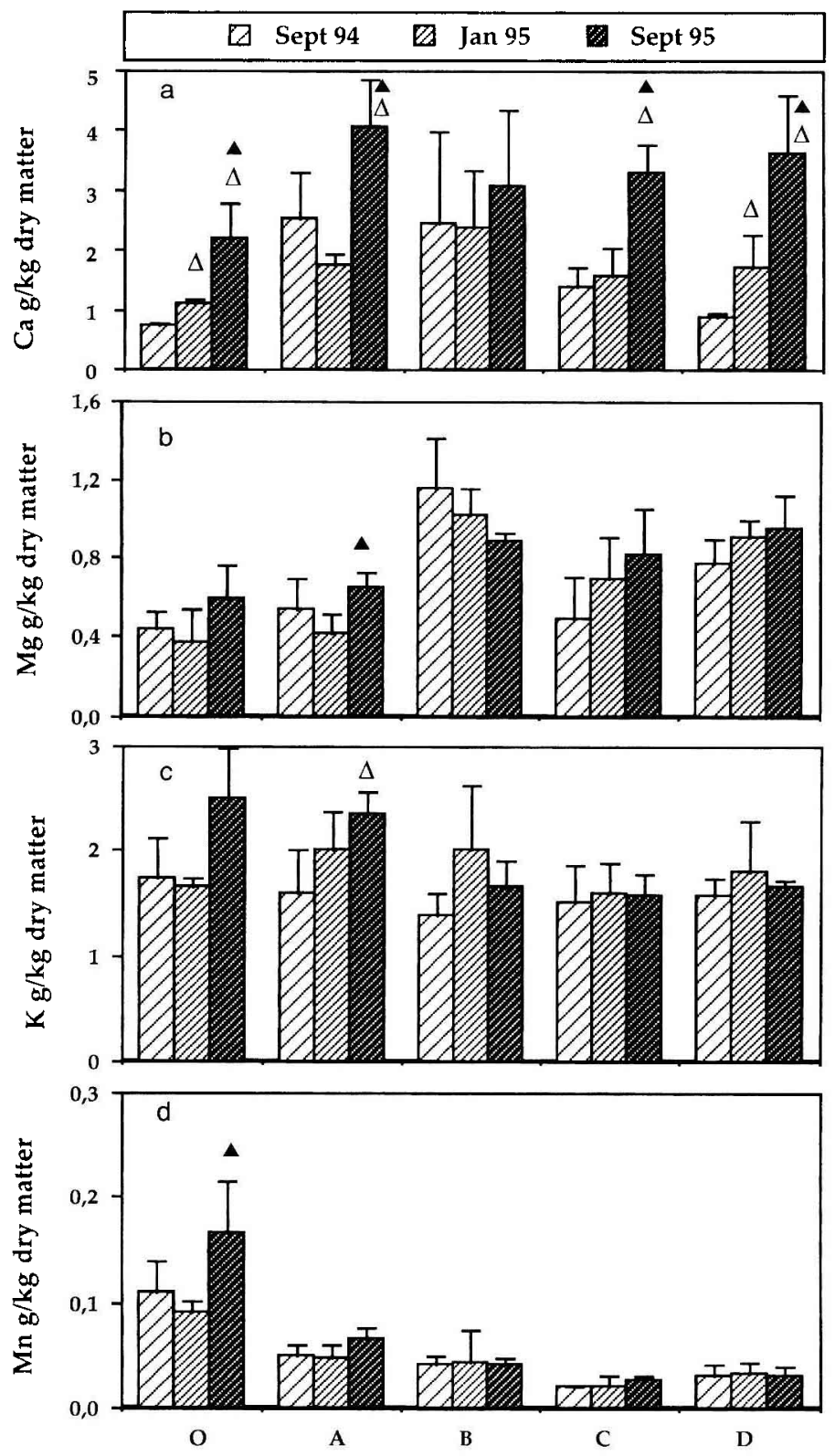

Fig 2. Effects of fertilization on calcium (a), magnesium (b), potassium (c) and manganese (d) concentrations ( $\mathrm{g} . \mathrm{kg}^{-1}$ dry matter) in chestnut de-barked stems. $(\wedge)$ and $(\boldsymbol{\Delta})$ cation concentrations varying significantly in comparison with September 1994 and January 1995, respectively, by Mann-Whitney $\mathrm{U}$ test (threshold $5 \%$ ). Abbreviations for treatments are the same as those in figure 1. 
(quick-lime as well as $\mathrm{CaMg}$ ) also revealed a fertilizer effect. The Mg levels followed the same pattern: they increased when magnesium was applied (fig 2b), and a tendancy to increase over time was observed for all treatments, except B. The concentration of $K$ decreased with the addition of fertilizer (fig 2c). The $\mathrm{K}$ levels increased in 1995 in $\mathrm{O}$ and $\mathrm{A}$ and remained constant for the others. The highest $\mathrm{Mn}$ levels (fig 2d) were obtained in $\mathrm{O}$ and gradually decreased from $A$ to $\mathrm{C}$ and $\mathrm{D}$. In addition, the $\mathrm{Mn}$ concentrations of $\mathrm{O}$ trees were higher in September 1995 than in 1994.

The Ca levels in bark (fig 3a) were double those of the control in treatments where $\mathrm{Ca}$ was supplied. They revealed an increase from September 1994 to September 1995 (except in the control), which was particularly marked in $\mathrm{A}, \mathrm{C}$ and $\mathrm{D}$. In figure $3 \mathrm{~b}$, an increase $(50 \%)$ in the $\mathrm{Mg}$ level was observed in $\mathrm{Mg}$ supplied trees as well as a significant $\mathrm{Mg}$ decrease from September 1994 to September 1995. The K levels showed no significant treatment effects. There was a trend in $\mathrm{K}$ concentration, an increase in $\mathrm{O}$ and $\mathrm{A}$ but a decrease in $\mathrm{C}$ and $\mathrm{D}$, over time (fig $3 \mathrm{c}$ ). The $\mathrm{Mn}$ concentrations (fig $3 \mathrm{~d}$ ) were twice as high in $\mathrm{O}$ and tended to gradually decrease from $\mathrm{A}$ to $\mathrm{C}$ and D.

The results presented in figure 4a show a strong fertilizer effect on Ca levels in leaves, which tripled in treatments where calcium was supplied. These levels remained similar, between harvest dates. In September 1994, an increase in $\mathrm{Mg}$ concentrations (fig 4b) was observed for the three treatments that contained a magnesium supply, whereas these levels decreased steeply and were statistically significant $(30-40 \%)$ in September 1995 (B, C and D). The pattern of K revealed highest levels in $\mathrm{O}$ and $\mathrm{A}$. This situation was more marked during the second year (fig 4c). The Mn levels (fig 4d) were higher in $\mathrm{O}$ and $\mathrm{A}$ than in the three other treatments in September 1994. In September
1995, the Mn level was also higher in O trees than in the others.

\section{DISCUSSION}

In forest nutrition studies (Hytonen, 1995), experiments are generally carried out over several years in order to obtain significant treatment effects and to limit the variability due to both climatic and biotic factors. It is evident that to work under natural conditions, many parameters and interactions must be managed and it is thus necessary to simplify the experiments. In this study, the experiments were conducted under closed conditions in a greenhouse. The plants were protected from the weather so that a number of physical and biological factors that can represent export (loss by percolation, flora, fauna, etc) or import (rainfall element, decomposition of pre-existing litter, etc) parameters were controlled in this study. Apart from the fact that the mineral composition of the substratum was already known (Freyssac et al, 1994), supplies were tightly controlled, deionized water was used for watering and finally the leaf mineral composition was quantified at leaf fall in order to take it into account (data not shown). This experimental approach results in a better understanding of fertilization effects by reducing annual variations in atmospheric and biotic factors (Ranger, 1981).

Following Bourgeois (1992), we confirmed that chestnut trees are able to grow for at least 2 years on an exchangeable element-poor substratum such as the $\mathrm{C}$ Horizon of mesotropic brown soil (Verger et al, 1985, 1994) watered only with totally deionized water. This growth capacity on a substratum poor in exchangeable elements could reveal an ability to draw mineral elements from the soil reserve, as hypothesized by Brethes and Nys (1975) with resinous trees. 

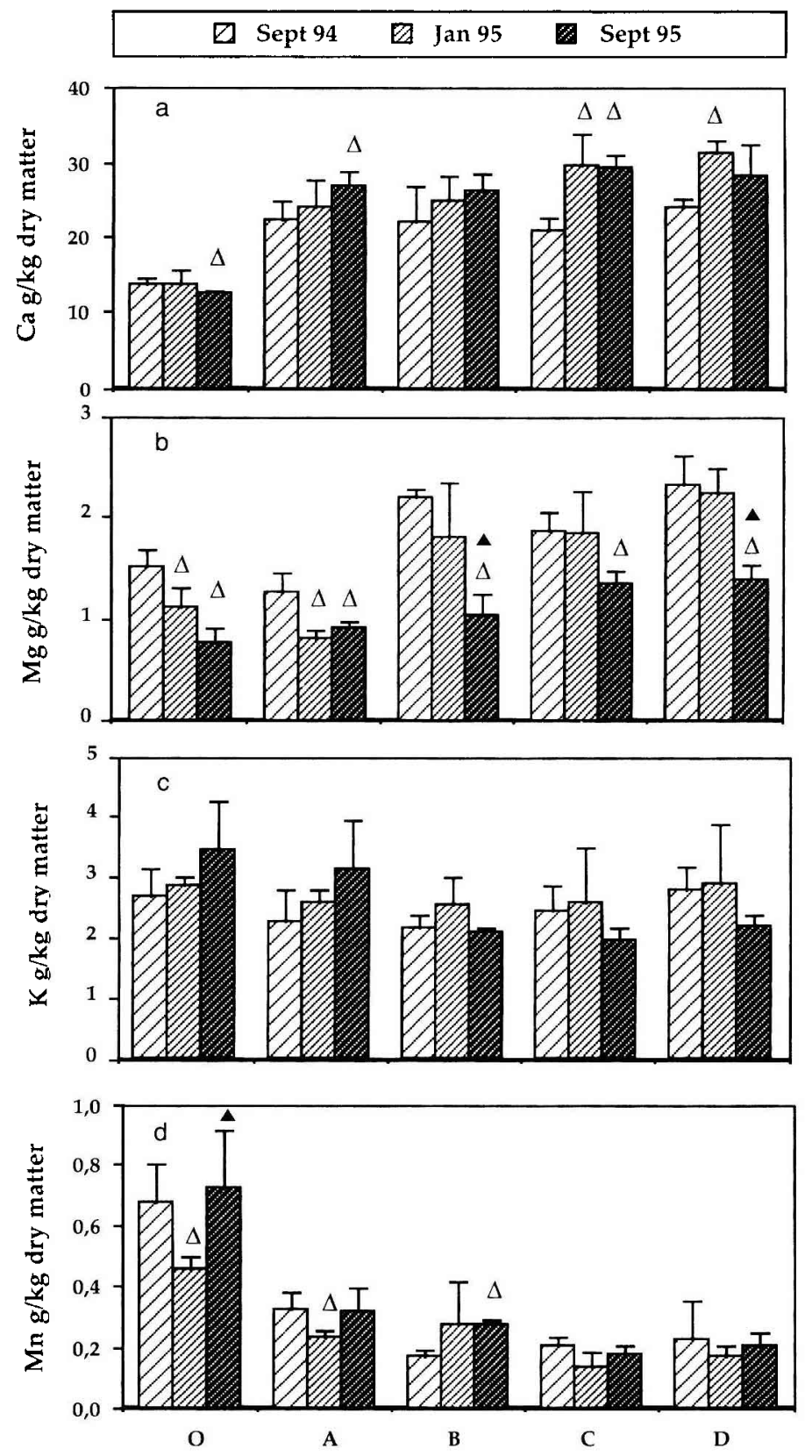

Fig 3. Effects of fertilization on calcium (a), magnesium (b), potassium (c) and manganese (d) concentrations $\left(\mathrm{g} . \mathrm{kg}^{-1}\right.$ dry matter $)$ in chestnut bark. $(\triangle)$ and $(\boldsymbol{\Delta})$ cation concentrations varying significantly in comparison with September 1994 and January 1995, respectively, by Mann-Whitney U test (threshold 5\%). Abbreviations for treatments are the same as those in figure 1. 

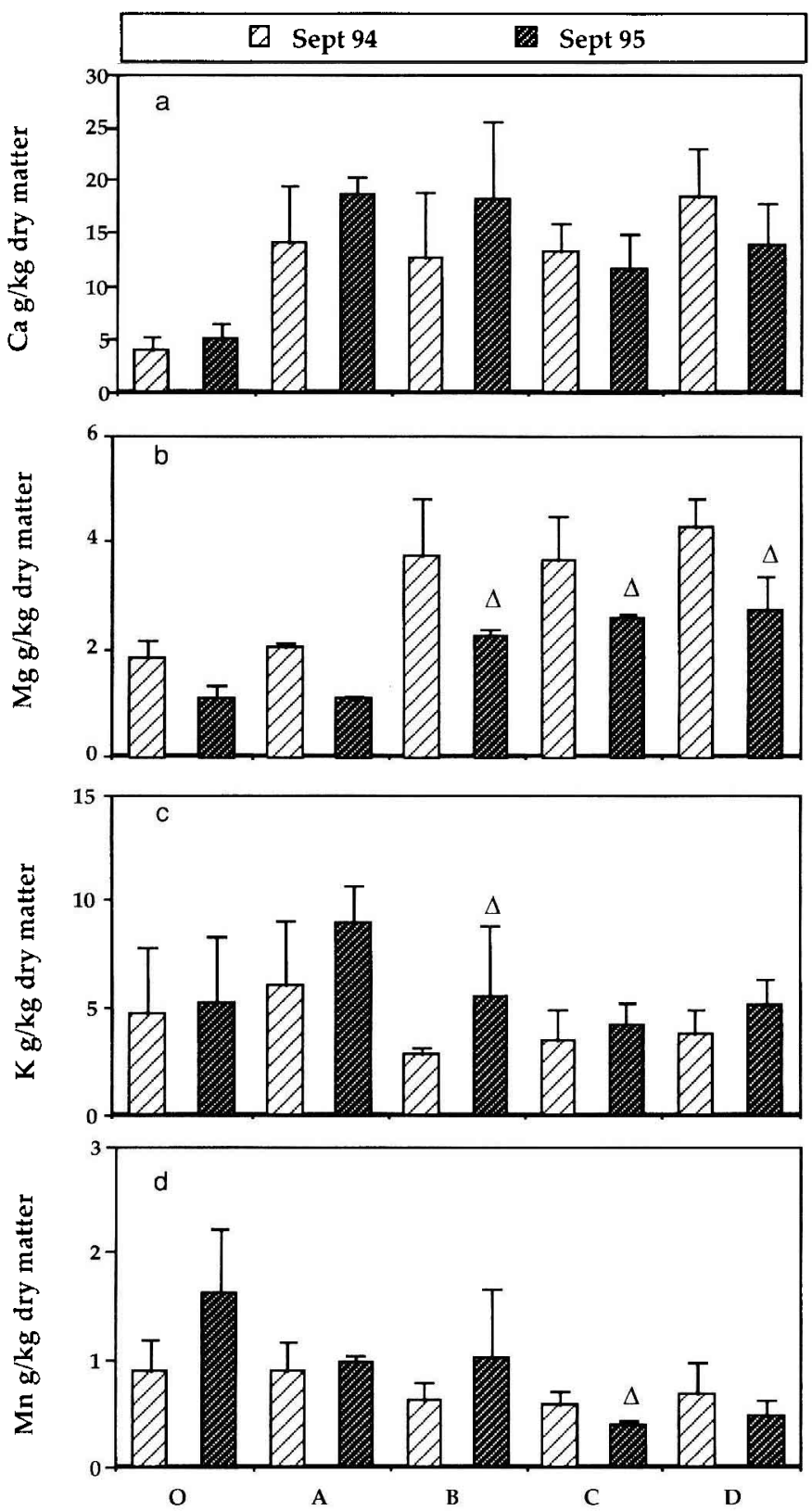

Fig 4. Effects of fertilization on calcium (a), magnesium (b), potassium (c) and manganese (d) concentrations ( $\mathrm{g} \cdot \mathrm{kg}^{-1}$ dry matter) in chestnut leaf. $(\triangle)$ cation concentrations varying significantly in comparison with September 1994, by Mann-Whitney U test (threshold 5\%). Abbreviations for treatments are the same as those in figure 1. 
Growth parameter analysis shows some differences depending on both culture duration and fertilizer effects. A slight growth increase was observed from September 1994, probably owing to NPK supply (C and D). The leaf areas followed a similar pattern. During the second year, these observations were confirmed. All growth parameters increased significantly following an NPK (including calcium and magnesium) supply, but to a lesser extent with CaMg. Some differences concerning leaf morphology and colour were also observed in 1995. Leaves were either rounded, large and deepgreen or small, elongated and yellow-green with or without an NPK supply, respectively (data not shown). Taken together these results give rise to two hypotheses: i) $\mathrm{Ca}$ and/or $\mathrm{Mg}$ are not the sole deficient element(s) in the substratum used; ii) the fertilizer supplies modify the cation balance in soil. The nutrient ratios in soil affect absorption and translocation, and consequently growth (Shear and Faust, 1980; Jadczuk and Lenz, 1994).

The addition of $\mathrm{Ca}$ and $\mathrm{CaMg}$ increases the growth, which shows the deficiency of both elements in the substratum. A greater effect on growth and foliage development is observed when NPK fertilizer is added, indicating that at least one of them (N, P or $\mathrm{K})$ is initially insufficient. In addition, nutrient supplies can modify the cation balance either by a direct effect or via a $\mathrm{pH}$ variation and consequently modify the cation absorption (Maas et al, 1969; lyengar and Reddy, 1993; Jadczuk and Lenz, 1994; Ramalho et al, 1995). Moreover, some studies show correlations between soil acidification and cation availability (Ross et al, 1985; Whigham and Richarson, 1988; Neilsen et al, 1994; Ljungström and Nihlgard, 1995). In our study, all the fertilizer supplies induce an increase in soil $\mathrm{pH}$. Used alone, calcium enhances the soil $\mathrm{pH}$ but less than when it is added with other elements ( $\mathrm{Mg}$ and NPKMg). Chestnut trees, which are known for their ability to grow in acid soils, have shown a marked tendancy to grow under slightly basic $\mathrm{pH}$ conditions. These results are not contradictary, indeed the basic $\mathrm{pH}$ is not related to limestone, which inhibits the growth of chestnut trees (Bourgeois, 1992).

The differences in both growth and foliage development that were observed between the first and second year could be attributed to nutrient storage within the plant, resulting from previous non-deficiency culture conditions. This is probably a sufficient reason to explain the marked growth responses during the second year.

In addition to the fertilizer effects on chestnut tree morphology, some fertilizer effects have been observed concerning the mineral contents. Results show different mineral levels according to the components tested. Thus, all minerals studied have the lowest concentrations in wood (de-barked stem) and root samples, whereas they are higher in bark and then in leaves for $\mathrm{Ca}$ and inversely for $\mathrm{Mg}, \mathrm{Mn}$ and $\mathrm{K}$. These results are in agreement with those reported in other species such as Scots pine (Ranger, 1981) and larch (Myre and Camire, 1994). In our experiments, the same trend is observed in mineral concentrations in all components, whatever the fertilizer effect. Moreover, we note that the leaf/any other component ratio (but only to a lesser extent with bark) of $\mathrm{Mn}$ concentrations are the highest (ten for $\mathrm{Mn}$ and three for $\mathrm{Ca}, \mathrm{Mg}$ and $\mathrm{K}$ ). Furthermore, the foliar area of the fourth leaf reveals the same pattern as the total foliage area and also the mineral content (data not shown). Thus, in agreement with previous works (Ljungström and Nihlgard, 1995; Ramalho et al, 1995), leaf sampling can be used to estimate the cation status in trees and is consequently a rapid method of revealing ion deficiencies. According to Ljungström and Nihlgard (1995), Ca and Mg concentrations increase markedly during the first year, with calcium and magnesium supplies, respectively. By contrast, the potassium supply 
has no effect on any of the mineral contents studied, including itself. This element may be present in sufficient proportions in the plant, taking into consideration the $\mathrm{K}$ level in leaves $(0.87 \%)$ under optimal nutritional conditions (Colin-Belgrand et al, 1993).

In addition, the concentration of each element varied differently within each component over time. For instance, the Ca level increased from September 1994 to September 1995, even under control conditions and more markedly with all other fertilizer supplies. This accumulation of $\mathrm{Ca}$, with no additional supply, is observed in all components. Thus, this cannot be explained by a redistribution of stored calcium from one component to others. According to our experimental conditions, the only calcium source for the young trees cultured with no supply was the substratum, poor in exchangeable mineral elements (Freyssac et al, 1994). Consequently, the enhancement of calcium concentrations observed in all plant components could reveal the ability of chestnut to draw up mineral elements from the soil reserve, as observed in resinous trees (Brethes and Nys, 1975), via a disorganization of clay colloids, which increases ion availability. The evolution of $\mathrm{Mg}$ concentrations was the reverse: a decrease was observed during the experimentation time under all conditions, especially in leaves and bark, because it could have been absorbed mainly during the first months of culture and to a lesser extent later. The difference between the accumulation levels of these cations can be explained by the lower mobility of Ca (Ferguson and Bollard, 1976; Marschner, 1986; Hytönen, 1995) or differences in absorption rate between calcium and magnesium, via interactions between cations (Maas et al, 1969; Jadczuk and Lenz, 1994). In order to fully understand these phenomena, it will be interesting to take the substratum cation content into account.

Finally, we would like to point out the case of Mn whose levels are higher under control conditions than all others. Other works show a decrease in leaf manganese concentration in relation to an increase in soil $\mathrm{pH}$ and a negative correlation between $\mathrm{Mn}$ leaf concentration and growth (Spiers and Braswell, 1994). Neilsen et al (1994) reported a maximum $\mathrm{Mn}$ content in leaves at pH 4.8 and a relationship between soil acidification and increasing solubility of toxic elements such as manganese and aluminium. In addition, variations in soil pH modify the cation availability. For example, a decrease in $\mathrm{pH}$ from 6.1 to 3.5 induces a 16 -fold increase in extractable $\mathrm{Mn}^{2+}$ (Ross et al, 1985). Thus, these manganese and aluminium availabilities can cause phytotoxicity and imbalanced nutrition, aggravating the cation deficiencies. Since a calcium supply induces a strong decrease in Mn level, this study, in agreement with Ljungström and Nihlgard (1995), suggests that the manganese content of a plant component can be used as a marker of calcium and perhaps other mineral deficiencies.

In conclusion, our study shows the impact of some fertilizations on both growth and some mineral contents of young chestnut trees. It would be interesting to study their effects over several years. Our results, concerning the low cation concentrations in debarked stem, calcium in particular, without fertilization, give support to the hypothesis concerning the potential role of calcium in ringshake. It will be necessary to study mechanical resistance of wood in correlation with calcium content in order to find out if calcium deficiency in situ influences the mechanical qualities of wood. In the near future, we aim to specify the localization of cations in situ, using SIMS (secondary ion mass spectrometry), which appeared to be a useful means of studying the calcium distribution in plant tissues (Jauncau et al. 1992; Roy et al, 1995). It will also be important to link calcium localization to the content and metabolism of pectins. 
Acknowledgment: We wish to thank Mr Alastair Balloch for linguistic advice.

\section{REFERENCES}

Bourgeois C (1992) Le châtaignier: un arbre, th bois. Institut pour le développement Forestier, Paris

Brethes A, Nys C (1975) Effets des résineux sur la fertilité des sols. Difficulté des recherches et premiers résultats. Sci Sol 1, 3-18

Chanson B, Lcban JM, Thibaut B (1989) La roulure du châtaignier (Castanea sativa Mill.). Forêt Méditerranéenne XI, 15-34

Colin-Belgrand M, Ranger J, Bouchon J, d'Argouges S (1993) Transferts internes d'éléments nutritifs dans le bois de châtaignier (Castanea sativa Mill.): approche dynamique sur une chronoséquence de peuplements: I. Distribution des éléménts minéraux. Acta Oecologica 14, 653-680)

Davis DE (1949) Some effects of calcium deficiency on the anatomy of Pinus tadea. An $J$ Bot 36, 276-282

Demarty M, Morvan C. Thellier M (1984) Calcium and the cell wall. Plant Cell Environ 7, $441-448$.

Ferguson IB, Bollard EG (1976) The movement of calcium in woody stems. Ann Bot 40, 1057-1065

Freyssac V, Rahmani A, Carlue M, Verger JP, Morvan H (1994) Contribution à l'étude de la roulure du châtaignier. Etude expérimentale des conséquences d'amendements calciques. I- Relation entre la composition minérale du milieu et celle de jeunes plants. Ann Sci Limousin 10, 25-34

Hoenig M, Vanderstappen R (1978) Dosage de Cd, $\mathrm{Cu}, \mathrm{Pb}, \mathrm{Zn}$ et $\mathrm{Mn}$ dans les végétaux par spectrométrie d'absorption atomique en flamme. Effets de la minéralisation. Analusis 6, 312-316

Hytonen J (1995) Effect of fertilizer treatment on the biomass production and nutrient uptake of short rotation willow on cut away Peatlands. Silva Fennica 29, 21-40

Iyengar ER, Reddy MP (1993) Crop response to salt stress: seawater application and prospects. In: Handbook of Plant and Crop Stress (M Pessarakli, ed), Marcel Dekker Inc, New York, 183-20I

Jadezuk E, Lenz F (1994) Effect of nutrient supply and fruit load on $\mathrm{K}$ concentration in plant organs of apple. Gartenhawissenschaft 59, 149-153

Jarvis M C (1984) Structure and propertics of pectin gels in plant cell walls. Plant Cell Environ 7, 153164

Jauneau A, Ripoll C, Rihouey C, Demarty M, Thoiron A, Martini F, Thellier M (1992) Localisation du Ca et Mg par microscopie ionique analytique dans des plantules de lin: utilisation d'une méthode de précipitation au pyroantimoniate de potassium. $C R$ Acad Sci 315 (III), 179-188
Liners F, Gaspar T, Van Cutsem P, (1994) Acetyl- and methyl-esterification of pectins of friable and compact sugar beet calli: consequences for inter cellular adhesion. Planta 192, 545-556

Ljungström M, Nihlgard B (1995) Effects of lime and phosphate additions on nutrient status and growth of bech (Fagus syluatica L) scedlings. For Ecol Manag 74, 133-148

Maas EV, Moore DP, Mason BJ (1969) Influence of calcium and magnesium on manganese absorption. Plant Phisiol 44, 796-800)

Mann HB, Whitney DR (1947) On a test of whether one of two random variables is stochasticaly larger than the other. Ann Math Statis 18, 52-54

Marschner H (1986) Mineral Nutrition of Higher Plants. Academic Press, London

Myre R Camire C ( 1994 ) Distribution de P, K, Ca, $\mathrm{Mg}, \mathrm{Mn}$ et Zn dans la tige des mélèzes européen ct laricin. Ann Sci For 51, 121-134

Neilsen GH, Parchomchuk P. Hogue EJ, Wolk WD, Lau OL (1994) Response of apple trees to fertigation-induced soil acidification. Can I Plant Sci 74 , 347-351

Ramalho JC, Rebelo MC. Santos ME, Antunes ML, Nunes MA (1995) Elfects of calcium deficiency on Coffea arbica. Nutrient changes and correlation of calcium levels with some photosynthetic parameters. Plant Soil 172,87-96

Ranger J (1981) Etude de la minéralomasse et du cycle biologique dans deux peuplements de Pin laricio de Corse dont l'un a été fertilisé à la plantation. Ann Sci For 38, 127-158

Ross GJ, Hoyt PB, Neilsen GH ( 1985 ) Soil chemical and mineralogical changes due to acidification in okanagan apple orchards. Can J Soil Sci 65, 347355

Roy S, Gillen G, Conway WS, Watada AE, Wergin WP (1995) Use of secondary ion mass spectrometry to image ${ }^{44}$ calcium uptake in the cell walls of apple fruits. Protoplasna 189, 163-172

Shear CB, Faust M (1980) Nutrition ranges in deciduous trec fruits and nuts. Hortic Rev 2, 146-163

Spiers JM, Braswell JH ( 1994) Response of 'Sterling' muscadine grape to calcium, magnesium and nitro gene fertilization. J Plant Nutr 17, 1739-1750)

Verger JP, Vilks A, Javellaud J, Botincau M (1985) Le taillis de châtaignier de la forêt communale de Cussac (87), rapport sol-vegetation. Colloques phytosociologiques XIV: Phytosociologie et Foresterie, Nancy

Verger JP, Domain Ph, Fournier JM, Maisonier C, Djomo JE (1994) Importance du calcium dans le développement in situ du taillis de châtaignier en Limousin. Ann Sci Limousin 1, 25-34

Whigham DF, Richardson CJ (1988) Soil and plant chemistry of an Atlantic white cedar wetland on the Inner Coastal Plain of Maryland. Can J Bot 66 , $568-576$ 